〈論文〉

\title{
多変量分析による琴湖江の水質評価
}

\section{Water Quality Estimation of the Kum-Ho River by Multivariate Analysis}

\author{
Yung-Kyu PARK*, Chul-Hee LEE*, \\ Hwi-Soo JUNG* and Shun-Hwa LEE*
}

* Department of Environment Engineering, Young Nam University, Dae Dong 214 Kyoung San City, Kyoung Book, 713-800 Korea

\begin{abstract}
The water quality of the Kum-Ho River was estimated by multivariate analysis. Results of the analysis were as follow as:

1. The water quality of the Kum-Ho river estimated by the factor scores were generally not different throughout the period of this research.

2. The cumulative proportion to the third principal components was $97.8 \%$.

3. The factor loadings of 14 water quality items studied were over 0.9 . The river appeared to be polluted by human activities and the waste water from nearby factories.

4. The flow of Kum-Ho river was closed related to $\mathrm{COD}_{(\mathrm{cr})}$ and the factor scores. The run-off loading rate, therefore, could be explained by $\mathrm{COD}_{(\mathrm{cr})}$ and factor scores. The run-off loading rate of the lower Kum-Ho river basin showed no significant variation, where the pollutions were mainly contributed by the point soures.
\end{abstract}

Key words : multivariate analysis, eigen values, cumulative proportion, factor loading, factor scores

\section{1.はじめに}

近年各種産業の発達と人口増加によって大都市近傍 の河川の污染は急激に進みつつあり，とくに韓国の場 合水道原水の $50 \%$ 以上を占めている河川水の污染はわ れわれの生活を圧迫する状態になってきている。この ような水質を改善するためには現在の河川の水質を正 確に把握し，水質改善のための総合的な管理・対策が 要求されている。

河川の水質は一般的に污染物質の指標として BOD, $\mathrm{DO}$, 栄養塩など特定污染項目を選定して評価する場合
が多い。しかし，河川水質は污染物質の発生源が多様 であるため污染項目相互間の相関性，河川の地理的条 件，気象的特性など様々な影響因子が複合しており， 評価することが非常に難しくなっている。このため, 河川水質の解析に用いる多変量解析は多数の項目を総 合的に取り扱うことのできる面から効果的な方法の一 つであると考えられる。

河川水質を総合的に解析するため，いくつかの総合 特性值（主成分）を抽出し，これらと水質特性の関係 あるいは発生源の関係を判断する基準を提供するため の多変量解析例はいくつか報告されている ${ }^{1) ~ 4) 。 ~}$ 
本研究で対象とした琴湖江水系は, 韓国第 3 の都市 大邱地域の各種工業用水の供給源として重要な役割を 果たしていたが，この流域の都市化によって水質污濁 はすでに深刻な問題になっている。本研究では，琴湖 江流域において水質調査を 6 回行い，まず調査回数の 妥当性を調査するため，調査回数を変数とした多変量 分析を行い，各平均值を用いて調査地点別の多変量分 析を総合的に評価し，さらに個々の水質特性值および 污染負荷に対する流量の関係を多変量分析による因子 得点を比較した。

\section{2 . 琴湖江水系の概要}

琴湖江の流路は延長が $70 \mathrm{~km}$ であり，洛東江の第一 支流として嶺南地方の中心部の 3 都市と 5 つの郡の各 種用水の供給と下・廃水の放流先として重要な河川に なっている。

流域面積は $2,260 \mathrm{~km}^{2}$, 流域人口 270 万人であり，その 源を迎日郡竹長面に発し，洛東江合流点である達城郡 多斯面江倉に到るまでに約40の大小支流を持つ。

調査地点はFig. 1 に示すような 5 地点である。St. 1 (永東橋) は琴湖江の上流部で永川市と 2 つの郡を通過 した地点である。St. 2(峨洋橋) は中流部で大都市で ある大邱市に流入する直前である。St. 3（西辺橋）は 大邱市民の生活下水によって污染の進行した地点であ
り，St. 4 (八達橋）はさらに工業団地を通過しその排 水の影響を受けた地点である。St. 5 (海浪橋) は下流 部であり，この後洛東江に合流している。

\section{3. 水質データ}

水質解析の基本資料は上記 St. 5 (海浪橋) までの 5 地点で'84年10から'85年 6 月までの間で 6 回の採水を 行い分析した。

多変量解析には，次の15項目の測定結果を用いた。

(1) $\mathrm{pH}$, (2)水温 $\left({ }^{\circ} \mathrm{C}\right)$, (3) $\mathrm{D}$ (飽和 $\left.\mathrm{DO}-\mathrm{DO}\right)$, (4) $\mathrm{COD}_{(\mathrm{cr})}$ $\left(\mathrm{mg} \cdot l^{-1}\right)$, (5) $\mathrm{BOD}_{5}\left(\mathrm{mg} \cdot l^{-1}\right)$, (6) SS $\left(\mathrm{mg} \cdot l^{-1}\right)$, (7) 電気伝導度 $\left(\mathrm{umho} \cdot \mathrm{cm}^{-1}\right)$, (8) $\mathrm{NH}_{3}-\mathrm{N}\left(\mathrm{mg} \cdot l^{-1}\right)$, (9) $\mathrm{NO}_{3}-\mathrm{N}\left(\mathrm{mg} \cdot l^{-1}\right)$, (10) $\mathrm{TKN}\left(\mathrm{mg} \cdot l^{-1}\right)$, (11) $\mathrm{PO}_{4}-\mathrm{P}(\mathrm{mg} \bullet$ $\left.l^{-1}\right)$, (12) $\operatorname{VSS}\left(\mathrm{mg} \cdot l^{-1}\right)$, (13) $\mathrm{TOC}\left(\mathrm{mg} \cdot l^{-1}\right)$, (14) $\mathrm{Cl}^{-}(\mathrm{mg} \bullet$ $\left.l^{-1}\right)$ ，(15)大腸菌 $\left(\mathrm{MPN} \cdot 100 \mathrm{~m} l^{-1}\right)$

\section{4. 解析方法}

\subsection{DO の処理}

主成分分析を用いて洛東江の水質を評価した金 ${ }^{1)}$ は，水質項目中 DO が BOD などの水質項目と逆相関 関係があることに気付き，飽和度の逆数の意味で， $\mathrm{DO}^{-1}$ と変換して利用した。しかし，DOが非常に少な いかゼロの場合，つまり琴湖江下流の海浪橋（St. 5) で $\mathrm{DO}^{-1}$ と表示する場合，他地点に比べ相対的に $\mathrm{DO}^{-1}$

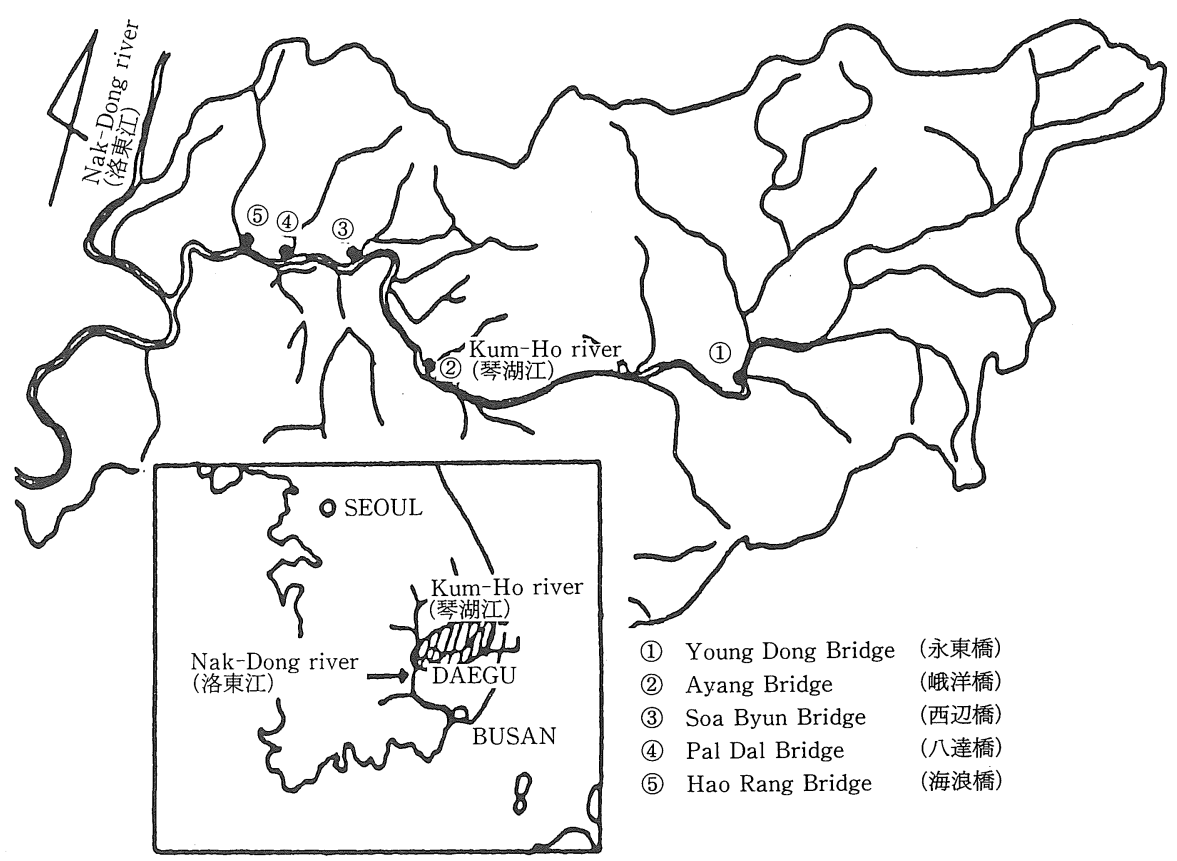

Fig. 1 Sampling stations at the Kum-Ho river 
があまりにも高くなっていることからこの地点では DO の再変換が要求されている。

従って，本研究では $\mathrm{DO}^{-1}$ の代わりに，その温度にお ける推定飽和 DO から DO を引いた值を DO 不足量,

D（飽和 DO-DO）とおきこれを用いて多変量解析を試 みた。

\section{2 主成分分析}

各項目ごとに平均值を計算した後，それぞれ正規分 布様式に変換した資料を用いて各地点ごとに調査回数 別の主成分分析を行い，因子得点を水質污染物質の濃 度と負荷量で示した。

\section{5. 結果および考察}

\section{1 水質調査回数別因子得点}

琴湖江の水質を 5 地点で分けて1984年10月〜1985年 6 月まで 6 回調査を行った結果から，もし調査期間中
に流域内の水質特性の変動あるいは特別な現象があれ ば地点別水質を総合的に評価するのは難しくなる。し かしながら，調査回数についての全体的傾向が一致す るか否かを調べるために主成分分析を行った結果を Fig. 2,3,4 に示した。この結果永東橋では第 6 回目の 調査結果のみ濃度が高く，その外はほとんど同じで あった。そして負荷から見ると，第 1 回目調査結果の み少し高くその外は同じであった。第 1 回と第 2 回を 除いた結果を第一主成分から見ると，調査期間が異 なっても全般的な傾向は上流（永東橋）での因子得点 が最も低く(濃度：-3.21-1.78, 負荷：-3.212.67)，下流にいくほど因子得点が高くなり，海浪橋で 最も高くなる (濃度： 5.656 .30 ，負荷： 5.77 6.58) 水質污染現象が明らかであり，調査回数別傾向がほと んど一致することから調査期間には特別な水質変動は 表れなかった。従って，季節的に水質が同質性を示し

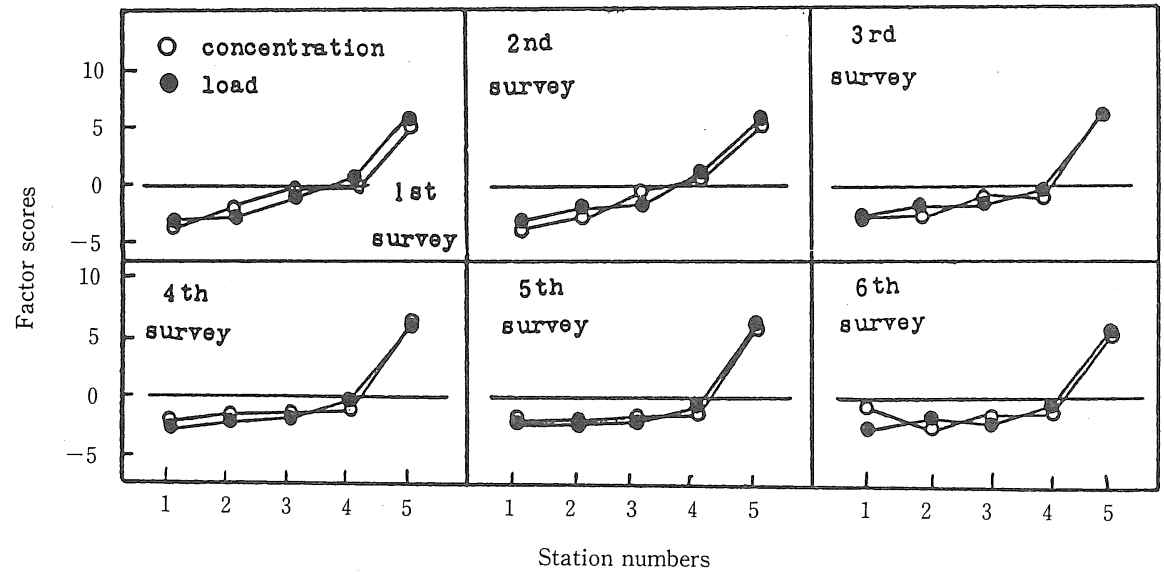

Fig. 2 Factor scores at each sampling station (1st principal components)

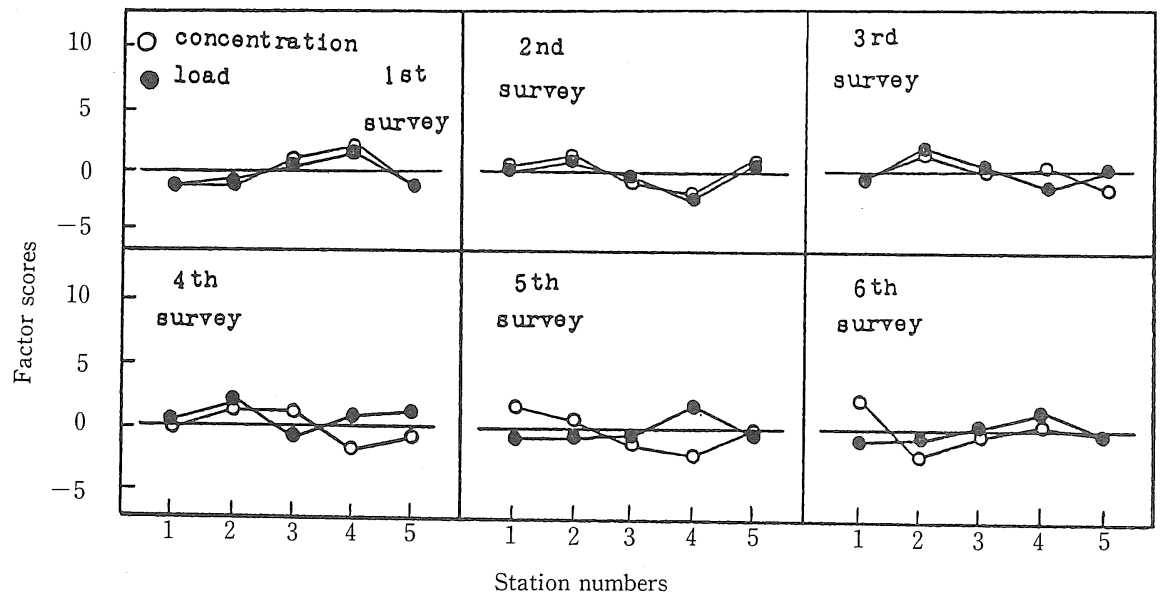

Fig. 3 Factor scores at each sampling station (2nd principal components) 


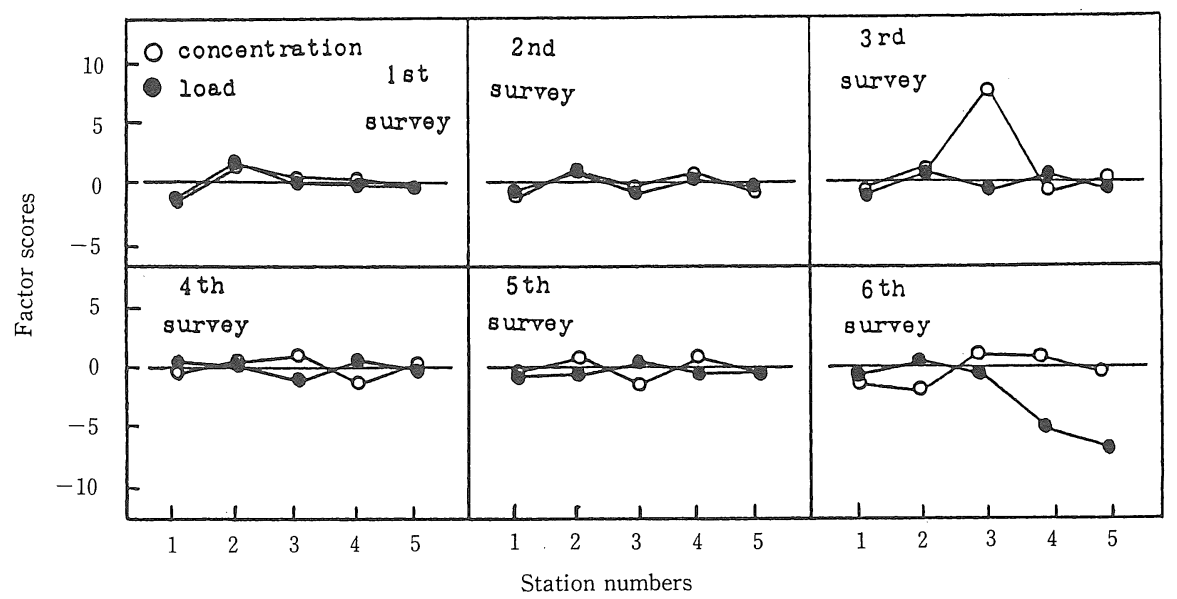

Fig. 4 Factor scores at each sampling station (3rd principal components)

Table 1 Water quality of the Kum-Ho river (6times average)

\begin{tabular}{|c|c|c|c|c|c|c|c|c|c|c|c|c|c|c|c|}
\hline & $\mathrm{pH}$ & $\begin{array}{l}\text { WT } \\
{ }^{\circ} \mathrm{C}\end{array}$ & $\underset{\mathrm{mg} \cdot l^{-1}}{\mathrm{D}}$ & $\begin{array}{l}\mathrm{COD}_{(\mathrm{Cr})} \\
\mathrm{mg} \cdot l^{-1}\end{array}$ & $\begin{array}{c}\mathrm{BOD} \\
\mathrm{mg} \cdot l^{-1}\end{array}$ & $\begin{array}{c}\mathrm{SS} \\
\mathrm{mg} \cdot l^{-1}\end{array}$ & $\begin{array}{c}\mathrm{COND} \\
\mu \mathrm{mh} 0^{\circ} \mathrm{cm}\end{array}$ & $\begin{array}{r}\mathrm{NH}_{3}-\mathrm{I} \\
{ }^{-1} \mathrm{mg} \cdot \mathrm{l}^{-1}\end{array}$ & $\begin{array}{l}\mathrm{NO}_{3}-\mathrm{N} \\
\mathrm{mg} \cdot l^{-1}\end{array}$ & $\underset{\mathrm{mgN}}{\mathrm{mg} \mathrm{l}^{-1}}$ & $\begin{array}{l}\mathrm{PO}_{4}-\mathrm{P} \\
\mathrm{mg} \cdot l^{-1}\end{array}$ & $\begin{array}{l}\mathrm{VSS} \\
\mathrm{mg} \cdot \mathrm{l}^{-1}\end{array}$ & $\begin{array}{l}\mathrm{TOC} \\
\mathrm{mg} \cdot \mathrm{l}^{-1}\end{array}$ & $\begin{array}{c}\mathrm{Cl}^{-} \\
\mathrm{mg} \cdot \mathrm{l}^{-1}\end{array}$ & $\begin{array}{c}\text { E. Coli } \\
\mathrm{MEN} / 100 \mathrm{~m} l^{-1}\end{array}$ \\
\hline St. 1 & 7.5 & 16.6 & -1.44 & 24.7 & 4.58 & 16.3 & 1026 & 0.072 & 2.567 & 1.942 & 0.022 & 5 & 9.83 & 17.1 & 2110 \\
\hline St. 2 & 8 & 17 & 0.35 & 17.5 & 8.15 & 27.33 & 1386 & 0.21 & 2.97 & 2.56 & 0.01 & 11 & 11.8 & 27.63 & 4600 \\
\hline St. 3 & 7.6 & 15.3 & 0.10 & 24.1 & 11.55 & 28.5 & 1398 & 1.39 & 2.37 & 5.08 & 0.22 & 12.62 & 17.32 & 25.3 & 6600 \\
\hline St. 4 & 7.5 & 15.8 & 2.76 & 32.9 & 14.88 & 33.97 & 1558 & 1.967 & 1.372 & 5.333 & 0.355 & 14.97 & 19.51 & 25.96 & 256000 \\
\hline St. 5 & 7.1 & 16.5 & 6.87 & 201 & 114 & 92.2 & 2832 & 8.73 & 1.631 & 18.83 & 1.257 & 41.67 & 93.39 & 58.2 & 1890000 \\
\hline
\end{tabular}

ていることが判断される。

\section{2 平均水質の特性}

6 回の調査を行った水質分析結果から大きな変動が 見られなかったので，調査を行ったデー夕結果を平均 して Table 1 に示した。

本調査期間の平均水質は下流にいくほど水質が悪化 し, 海浪橋(St. 5) では BOD $114 \mathrm{mg} \cdot l^{-1}, \mathrm{NH}_{3}-\mathrm{N} 8.73$ $\mathrm{mg} \cdot l^{-1}, \mathrm{PO}_{4}-\mathrm{P} 1.257 \mathrm{mg} \bullet l^{-1}$ であり, 污濁がかなり進 んだことを示した。 $\mathrm{pH}$ の変化によると上流に比べ下 流の方が低くなり，琴湖江の水質が多様な污染源に よって酸性化していると考えられる。また, $\mathrm{NO}_{3}-\mathrm{N}$ が 下流の方が低くなることは，上流では硝化作用によっ て $\mathrm{NH}_{3}-\mathrm{N}$ が $\mathrm{NO}_{3}-\mathrm{N}$ に変換し下流にいくほど $\mathrm{DO}$ が 低くなり嫌気状態に進みつつあり, 脱窒が起こりやす くなって $\mathrm{NO}_{3}-\mathrm{N}$ が減少したためと思われる。

\section{3 水質特性の相関性}

以上の 6 回の平均水質特性を用いて選択された15個 の水質項目間の相関係数を求めて Table 2 に示した。

相関係数の解析は研究者によって差があるのでここ に用いた方法は Guilford の相関係数の解析基準に よって検討した。その基準を次に示す。 $\mathrm{r}<0.20:$ 無視できる相関 $0.20<\mathrm{r}<0.40:$ 低い相関 $0.40<\mathrm{r}<0.70$ : 比較的高い相関

$0.70<\mathrm{r}<0.90:$ 高い相関

$0.90<\mathrm{r} \quad:$ 信頼できる相関

Table 2 の水質特性項目間の相関で $\mathrm{NO}_{3}-\mathrm{N}$ は比較 的高い相関 $(0.4<\mathrm{r}<0.7), \mathrm{pH}$ は高い相関 $(0.7<\mathrm{r}<$ $0.9)$ を示し, 他の DO, COD, BOD, SS, 電気伝導度, $\mathrm{NH}_{3}-\mathrm{N}, \mathrm{TKN}, \mathrm{PO}_{4}-\mathrm{P}, \mathrm{VSS}, \mathrm{TOC}, \mathrm{Cl}^{-}$, 大腸菌群 は全体的に信頼できる相関性 $(r>0.90)$ を持っていた。

\section{4 固有值 (Eigen Values) と累積寄与率 (Cumula-} tive Proportion)

6 回調査を行った平均水質を相関関係行列によって 固有値および固有ベクターを求めて寄与率と累積寄与 率を計算した結果を Table 3 に示す。

また毎調査回数別で 6 回の結果を計算して主成分の 寄与率および累積寄与率を Fig. 5 に示した。平均水質 で求めた第一主成分の寄与率は $85.1 \%$ ，第二主成分の 寄与率と累積寄与率は各々 $10.1 \% ， 95.2 \%$ ，第三主成 分は各々 $2.6 \% ， 97.8 \%$ であった。また，固有值が 1.5 以上である第二主成分までの 15 個の水質特性值が持っ ている情報の平均 $95.2 \%$ 以上が説明されているため, 項目が多い場合水質様相を要約するには満足できる。 
Table 2 Correlation coefficients among 15 items

\begin{tabular}{|c|c|c|c|c|c|c|c|c|c|c|c|c|c|c|c|}
\hline & $\mathrm{pH}$ & WT & D & $\operatorname{COD}(x)$ & $\mathrm{BOD}_{8}$ & SS & COND & $\mathrm{NH}_{3}-\mathrm{N}$ & $\mathrm{NO}_{3}-\mathrm{N}$ & Tha & $\mathrm{PO}_{4}-\mathrm{P}$ & VSS & TOC & $\mathrm{Cl}^{-}$ & E. $\operatorname{col} 11$ \\
\hline $\mathrm{pH}$ & 1 & & & & & & & & & & & & & & \\
\hline WT & .2004 & 1 & & & & & & & & & & & & & \\
\hline D & -.6996 & .0160 & 1 & & & & & & & & & & & & \\
\hline $\operatorname{COD}_{(\mathrm{Cr})}$ & -.8013 & .1736 & .9033 & 1 & & & & & & & & & & & \\
\hline$B O D_{8}$ & -.7746 & .1578 & .9183 & .9978 & 1 & & & & & & & & & & \\
\hline SS & -.7332 & .1065 & .9581 & .9803 & .9903 & 1 & & & & & & & & & \\
\hline COND. & -.7047 & .0844 & .9705 & .9641 & .9780 & .9975 & 1 & & & & & & & & \\
\hline $\mathrm{NH}_{3}-\mathrm{NH}$ & -.8128 & .0290 & .9495 & .9845 & .9892 & .9916 & .9850 & 1 & & & & & & & \\
\hline $\mathrm{NO}_{3}-\mathrm{N}$ & .7419 & .4290 & -.7233 & -.5207 & -.5178 & -.5639 & -.5801 & -.0229 & 1 & & & & & & \\
\hline TEN & -.7992 & .0165 & .9426 & .9823 & .9889 & .9920 & .9359 & .9939 & -.5994 & 1 & & & & & \\
\hline $\mathrm{PO}_{8}-\mathrm{P}$ & .82000 & .0016 & .9608 & .9760 & .9611 & .9881 & .9838 & .9986 & -.6625 & .9960 & 1 & & & & \\
\hline vss & -.7334 & .0773 & .9606 & .9755 & .9868 & .9994 & .9984 & .9921 & -.5741 & .9933 & .9844 & 1 & & & \\
\hline TOC & -.7866 & .1236 & .9240 & .9967 & .9994 & .9917 & .9803 & .9935 & -.5392 & .9934 & .9865 & .9892 & 1 & & \\
\hline $\mathrm{Cl}^{-}$ & -.6449 & .1642 & .9388 & .9618 & .9774 & .9918 & .9922 & .9684 & -.4742 & .9726 & .9711 & 9909 & .9764 & 1 & \\
\hline E. $\infty 11$ & -.7951 & .1683 & .9329 & 9966 & .9963 & .9876 & .9756 & .9892 & -.5675 & .9849 & .9843 & .9831 & .9957 & .9677 & 1 \\
\hline
\end{tabular}

Table 3 Eigen values of principal component analysis with 15 items.

\begin{tabular}{|c|c|c|c|c|}
\hline \multirow{2}{*}{ Items } & \multicolumn{4}{|c|}{ Eigen vector } \\
\hline & $\mathrm{PC}-1$ & $\mathrm{PC}-2$ & $\mathrm{PC}-3$ & $\mathrm{PC}-4$ \\
\hline $\mathrm{pH}$ & -.2252 & .3017 & .6363 & -.4138 \\
\hline WT & .0166 & .7485 & -.5060 & -.3645 \\
\hline $\mathrm{D}$ & .2 .83 & -.0632 & .1585 & -.4288 \\
\hline $\mathrm{COD}_{(\mathrm{Cr})}$ & .2763 & .1001 & -.1371 & .1506 \\
\hline $\mathrm{BOD}_{5}$ & .2769 & .1037 & -.0360 & .1087 \\
\hline SS & .2778 & .0644 & .1518 & -.0087 \\
\hline COND & .2775 & .0521 & .2324 & -.0522 \\
\hline $\mathrm{NH}_{3}-\mathrm{N}$ & .2797 & -.0099 & .0262 & .0787 \\
\hline $\mathrm{NO}_{3}-\mathrm{N}$ & -.1763 & .5303 & .3039 & .4581 \\
\hline TKN & .2789 & -.0553 & .0909 & .1277 \\
\hline $\mathrm{PO}_{4}-\mathrm{P}$ & .2796 & -.9432 & .0169 & .0379 \\
\hline VSS & .2778 & .0442 & .1518 & -.0087 \\
\hline TOC & .2769 & .0730 & -.0257 & .1087 \\
\hline $\mathrm{Cl}^{-}$ & .2718 & .1399 & .2509 & -.0650 \\
\hline E. Coil & .2769 & .0829 & -.1247 & .0391 \\
\hline E. V & 12.7630 & 1.5121 & .3912 & .3298 \\
\hline P. T. V & .8510 & .1010 & .0260 & .0220 \\
\hline C. $\mathrm{P}$ & .8510 & .9520 & .9780 & .1000 \\
\hline
\end{tabular}

E.V =Eigen values

P.T.V = Proportion of total variance

C.P = Cumulative proportions

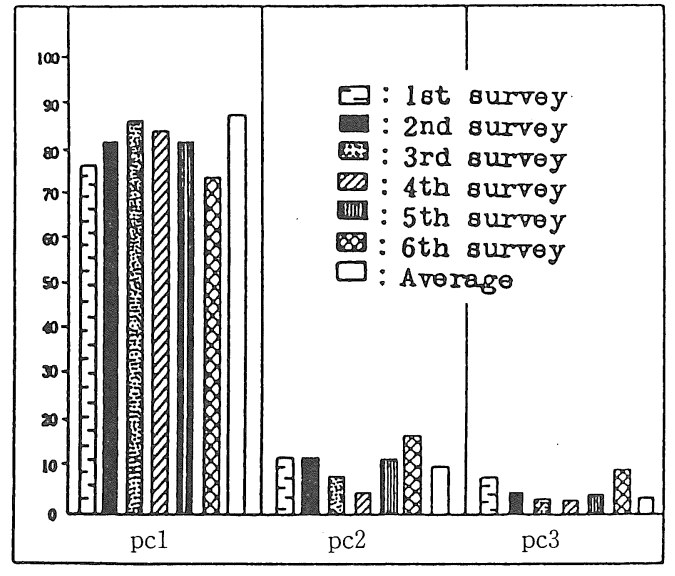

Fig. 5 Proportion for each principal components

\section{5 因子負荷量 (Factor loadings) と寄与度 (Com- munality)}

各主成分と水質特性の相関を説明する因子負荷量は 固有值と固有ベクターにより求められ，特定水質特性 が持っている総情報の各主成分に記憶される量を寄与 度とする時，第一主成分から第四主成分までの因子負 荷量と第一主成分から第三主成分までの寄与度を求め た結果を Table 4 に示した。

因子負荷量は第一主成分で水温を除いて全項目が 
Table 4 Factor loading and communality of principal components analysis with 15 items.

\begin{tabular}{|c|c|c|c|c|c|c|c|}
\hline \multirow{2}{*}{ Items } & \multicolumn{4}{|c|}{ Factor loadings $\left(r_{\mathrm{ki}}\right)$} & \multicolumn{3}{|c|}{ communality $\left(\mathrm{r}_{\mathrm{ki}}^{2}\right)$} \\
\hline & $\mathrm{PC} 1$ & $\mathrm{PC} 2$ & PC3 & $\mathrm{PC} 4$ & lst & 1st-2nd & 1 st-3rd \\
\hline $\mathrm{pH}$ & -.804 & .371 & .404 & -.238 & .6464 & .7840 & .9472 \\
\hline WT & .059 & .092 & -.316 & -.209 & .0034 & .0118 & .1110 \\
\hline $\mathrm{D}$ & .958 & -.078 & .099 & -.246 & .9177 & .9237 & .9330 \\
\hline $\mathrm{COD}_{(\mathrm{Cr})}$ & .987 & .123 & -.066 & .870 & .9741 & .9892 & .9935 \\
\hline $\mathrm{BOD}_{5}$ & .989 & .128 & -.023 & .062 & .9781 & .9932 & .9937 \\
\hline SS & .993 & .079 & .095 & -.005 & .9860 & .9922 & 1.0000 \\
\hline COND & .992 & .064 & -.145 & -.030 & .9840 & .9880 & 1.0000 \\
\hline $\mathrm{NH}_{3}-\mathrm{N}$ & 1.000 & -.012 & .016 & .045 & 1.0000 & 1.0000 & 1.0000 \\
\hline $\mathrm{NO}_{3}-\mathrm{N}$ & -.630 & .252 & .190 & .378 & .3969 & .4604 & .4965 \\
\hline TKN & .996 & .007 & .057 & .073 & .9920 & .9920 & .9952 \\
\hline $\mathrm{PO}_{4}-\mathrm{P}$ & .999 & -.053 & .011 & .022 & .9980 & 1.0000 & 1.0000 \\
\hline VSS & .997 & .034 & .093 & .005 & .9940 & .9951 & 1.0000 \\
\hline TOC & .989 & .090 & -.016 & .062 & .9781 & .9862 & .9864 \\
\hline $\mathrm{Cl}^{-}$ & .971 & .172 & .153 & -.037 & .9428 & .9723 & .9957 \\
\hline E. Coil & .990 & .102 & -.073 & .022 & .9802 & .9905 & .9958 \\
\hline
\end{tabular}

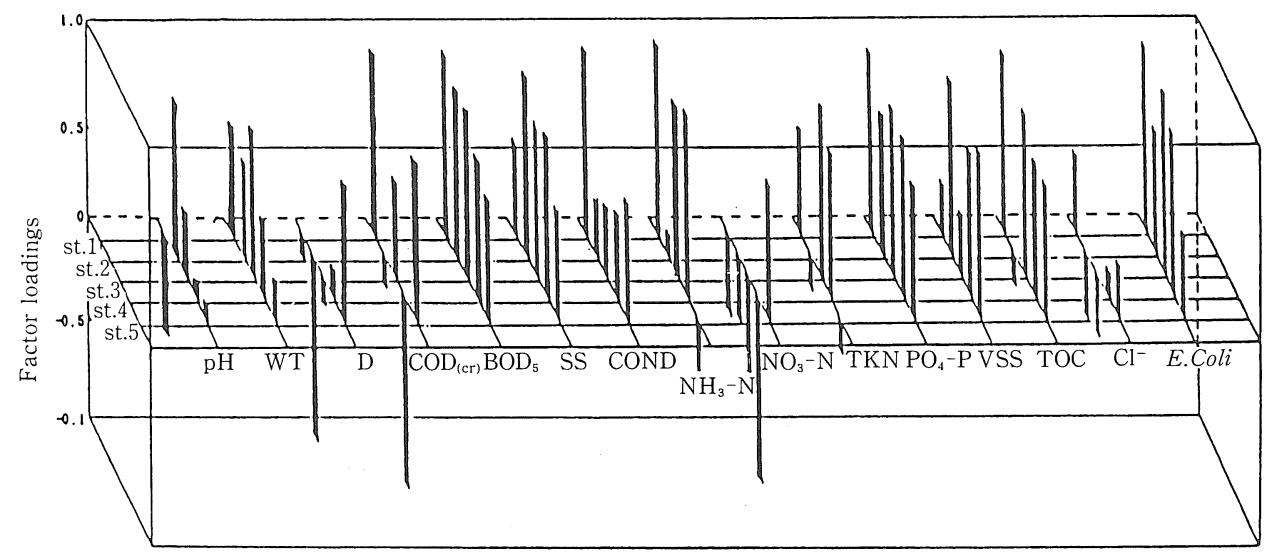

Fig. 6 Factor loadings of water quality elements for the 1st principal components at the each station (Base: concentration)

0.9 以上を示し, ほとんどが生活下水と工業廃水による 水質污染源であり，各水質項目の寄与度は，第一主成 分に水温, $\mathrm{pH}, \mathrm{NO}_{3}-\mathrm{N}$ 以外の項目は $91.8 \%$ 以上で, 第二主成分では水温が $84.6 \%, \mathrm{NO}_{3}-\mathrm{N}$ が $42.5 \%$ に なった。

また，各主成分まで全体水質項目の累積寄与度は総 変量が持っている情報の $97.8 \%$ (Table 3) が第三主成 分までに寄与しているし，第三主成分までを共通変量 (Common Variance) とする時，共通変量の $87 \%$ が第 一主成分に，10.3\%が第二主成分に，2.66\%が第三主 成分に各々寄与している。

第一主成分の因子負荷量を各地点ごとに濃度別, 負
荷別，6 回平均別で濃度，負荷量を図示すると Fig. 6, 7，8，9 のようになる。Fig.6 で峨洋橋の $\mathrm{NO}_{3}-\mathrm{N}$ と D が負を示すことは哦洋橋の高い BOD に比べて DO 相 関関係が高いので BOD，COD など水質污染項目で逆 相関を示すことに基づく。 $\mathrm{NO}_{3}-\mathrm{N}$ が逆相関を示すの は，上述したように下流にいくほど $\mathrm{N}_{2}$ 循環(有機 $\mathrm{N}>$ $\left.\mathrm{NH}_{3}-\mathrm{N}>\mathrm{NO}_{2}-\mathrm{N}>\mathrm{NO}_{3}-\mathrm{N}>\mathrm{N}_{2}\right)$ による脱窒の影響 と考えられる。

\section{6 因子得点 (Factor Scores)}

調査地点で主成分因子得点を求めた結果を Table 5 に示す。第一主成分の各地点別因子得点の傾向は Table 1 と Fig. 2，3，4 に示したように D, $\mathrm{BOD}_{5}, \mathrm{SS}$, 


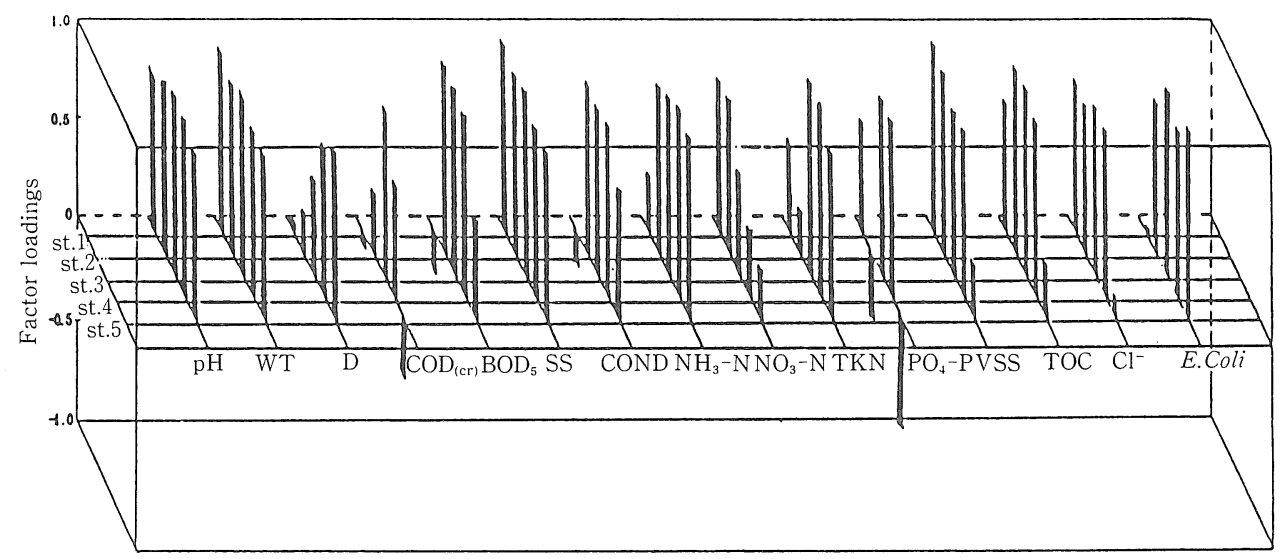

Fig. 7 Factor loadings of water quality elements for the 1st principal components at the each station (Base: pollutional load)

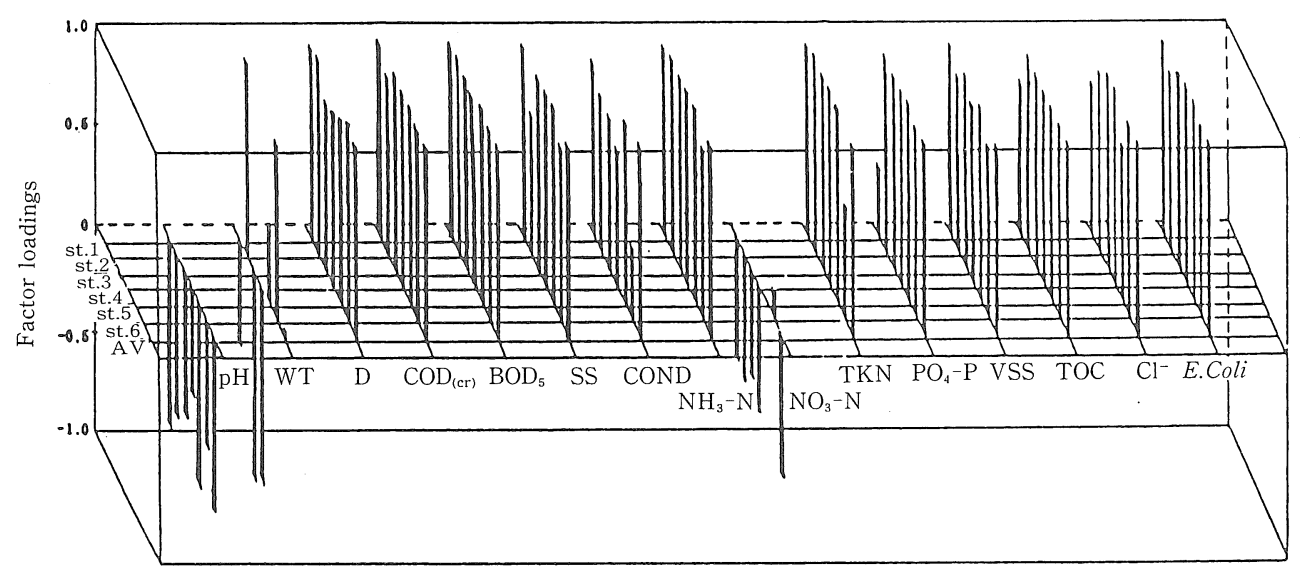

Fig. 8 Factor loadings of water quality elements for the 1st principal components at the each station (Base: concentration)

VSS， $\mathrm{NH}_{3}-\mathrm{N} ， \mathrm{TKN}, \mathrm{TOC}, E$. Coli の各地点別水 質変動が非常に類似性を持っているから琴湖江全体の
水質変化を予測することができる。第二主成分は $\mathrm{pH}$ ， 水温の影響が大きい。第三主成分以上は上述したよう 


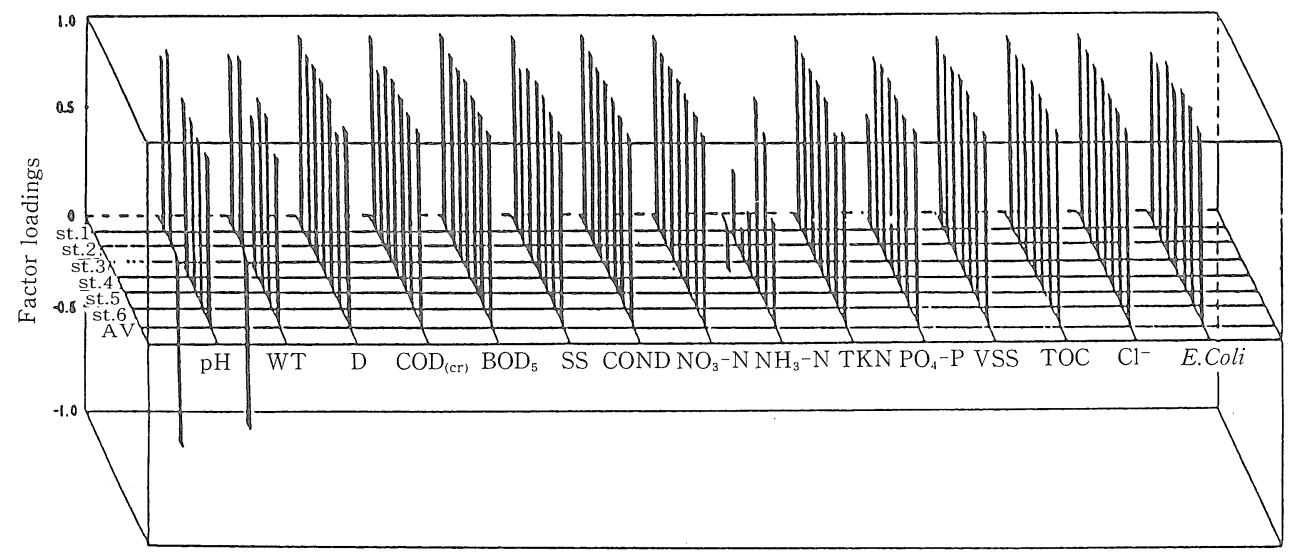

Fig. 9 Factor loadings of water quality elements for the 1st principal components at the each station (Base: pollutional load)

Table 5 Factor scores at each sampling stations

\begin{tabular}{|c|rrrr|}
\hline \multirow{2}{*}{ Stations } & \multicolumn{4}{|c|}{ Factor scores } \\
\cline { 2 - 5 } & PC-1 & PC-2 & PC-3 & PC-4 \\
\hline St.1 & -2.4153 & 0.3270 & -0.9256 & 0.3990 \\
St.2 & -2.1238 & 1.6377 & 0.4739 & -0.5596 \\
St.3 & -1.3435 & -1.0430 & 0.6728 & 0.6269 \\
St.4 & -0.3389 & -1.3643 & -0.1635 & -0.7902 \\
St.5 & 6.2236 & 0.3925 & -0.0626 & 0.1239 \\
\hline
\end{tabular}

に寄与率が少なくなったので略す。

因子得点は各地点の平均水質特性の相対的な様相を 示し，河川水質の総合的な評価は多変量分析として解 析するのが望ましく，また特定水質の指標を評価する ときは因子負荷量が低い項目は除外することが良いと 判断される。

また，河川水質の評価に因子得点を用いるためには 上流から下流まで等区間で水質調査地点を選定しなけ ればならない。しかし，実際に等区間で水質調査地点 を選定するのは諸般の事情で難しいことが多く，水質 調査地点の選定は非常に重要となる。

本調査での結果を総合的に見ると第一主成分の因子 得点は永東橋 (St. 1) でー2.415であり，下流ほど得点 值が高くなって八達橋 (St. 4) でー0.340とした污染現 象を示しているが地点全体因子得点の平均值以下であ る。しかし，海浪橋（St. 5) では励染がとくに激しく 6.224 であった。

\section{7 园子得点および水質特性と流量との関係}

Fig. 10 は各地点ごとの調査回数別流量と因子得点 関係および $\mathrm{COD}_{(\mathrm{Cr})}$ 負荷量との関係を示した。上流永
東橋 (St. 1) では $\mathrm{COD}_{(\mathrm{Cr})}$ が因子得点より流量との関係 が安定することが示されるが，下流では因子得点の方 が優れていることが認められる。また，上流では流量 の増加によって因子得点および $\mathrm{COD}_{(\mathrm{Cr})}$ 負荷量は急に 増加し，下流に行くほど流量による因子得点および $\mathrm{COD}_{(\mathrm{Cr})}$ 負荷量の増加程度が緩慢であった。最下流の海 浪橋においては一定流量以上での因子得点および $\mathrm{COD}_{(\mathrm{Cr})}$ 負荷量はほとんど一定である。

これは公共水路に自浄作用を考慮した污濁負荷の值 を排出負荷量とすると，上流流域では点的污染源によ る污染発生量より非点的污染源の污染発生量の比重が 大きいため，降雨による河川流量の増加によって排出 負荷量が大きくなるためである。また下流にいくほど 点的污染源の比重が増加してとくに海浪橋では大邱市 の点的污染源の影響が極めて大きくなる。すなわち， 点的污染源の洉染発生量は河川流量の変動に関係なく 一定であることにする。したがって，琴湖江全体流域 負荷量がすべて集められる下流では安定していること がわかる。

\section{6.まとぬ}

以上のように多変量分析を利用して琴湖江水質を総 合的に評価するため，主成分分析を行った。

結果をまとめると次の通りである。

1. 調査期間中に琴湖江流域の水質を因子得点で評 価した結果，特別な現象は見られず季節的に同質性を 示した。

2 . 第三主成分までの累積寄与率が $97.8 \%$ 高い值 を示した。 
st. 1

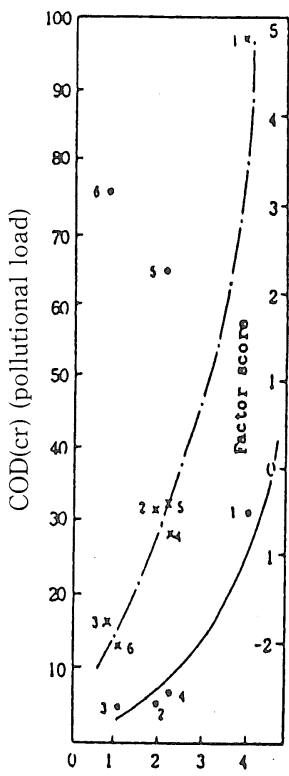

st. 2

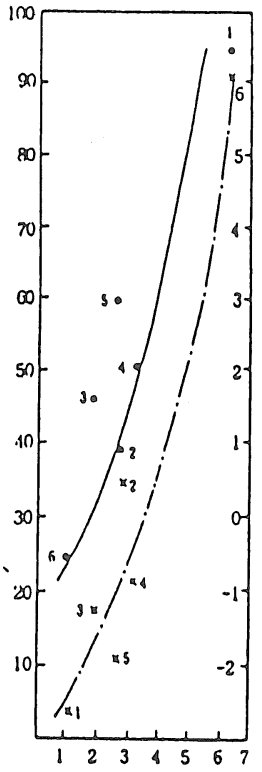

st. 3

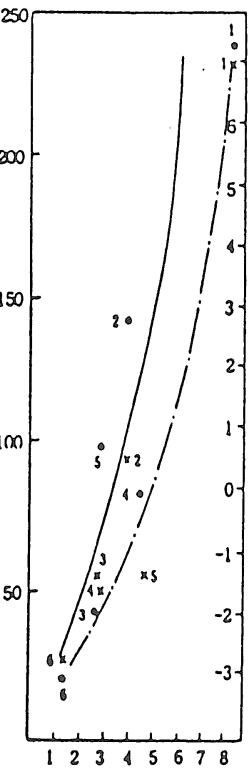

st. 4

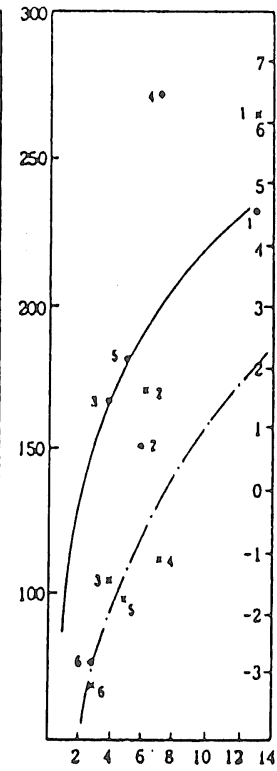

st. 5

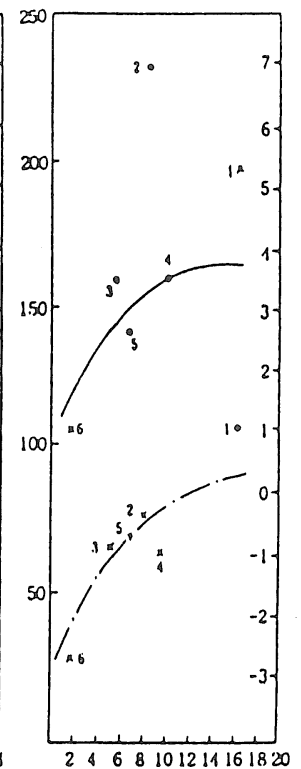

Flow rate $\left(\mathrm{m}^{2} \cdot \mathrm{sec}^{-1}\right)$

Fig. 10 Relation of water quality factor score and $\mathrm{COD}_{(\mathrm{cr})}$ by times for elimination (Base: pollutional load)

: $\mathrm{COD}_{(\mathrm{Cr})} \times$ : Factor score

3 . 第一主成分には水温を除いた 14 項目の水質特性 の因子負荷量が 0.9 以上の高い值を示し,生活下水と工 業廃水による水質污染項目と近い関係があることを示 した。

4 . 水質特性と流量との関係で, COD と総合水質特 性である因子得点は流量と明らかな関係が認められ た。また，点污染源による影響を大きく受ける琴湖江 の下流では河川流量変動による污染物質の排出負荷量 の変動はほとんどなかった。

（原稿受理 1990年 9 月12日）

\section{引用 文 献}

1）金 仁煥（1985）多変量分析による洛東江水質の評価，嶺南 大学環境大学院環境工学科学位論文集。

2 ) 吉見洋他（1982）相模川水系の水質分析について，水質污濁 研究, 5, 193-200.

3 ) 呉英敏，白成玉 (1984) 主成分分析を利用した河川水質資料 の解析, Journal of Korea Environment Engineerings 6(1), 57.

4 ) 広崎昭太 (1985) 多変量解析法の水質評価への応用, 工業用 水, $319,3-45$.

5 ) 吳澤変 (1985) 社会科学 DATA 分析法, 図書出版ナナム, 190, 303-343. 


\section{論文要 旨}

\section{連続流れコロイド滴定法によるカチオン性高分子凝集剈の定量}

五十嵐千秋*

* (株)荏原総合研究所

〈水質污濁研究 Vol.14 No.1(1991) pp.31 37〉

コロイド滴定法を連続流れ分析化してカチオン性有機高分子凝集剂を定量するために，二波長測光セルを用 いて滴定終点を設定する方法を検討した。溶存塩類および濁度等の影響を調査し，連続流れ分析計を試作して 以下の知見を得た。

1 ）各測定波長に扔ける透過光出力の差を用いてトルイジンブル指示薬の変色反応を検知し, 滴定剤の添加直 前の透過光出力の差を定数倍した值を滴定終点とすれば，滴定終点をあらかじめ設定することができる。

2 ）該定数を 0.8 とて, 指示薬の変色反応が始まる領域に滴定終点を定義すると,イオン強度が約 0.04 以下の 試料は無希釈で測定可能である。

3 ）本法に及ぼす濁度の影響は，約150度以下の試料では無視できる。

4 ）試作連続流れ分析計は， $0 \sim 0.1 \mathrm{meq} \cdot l^{-1}$ の範囲で応答性および精度が良好である。

\section{多変量分析による琴湖江の水質評価}

朴永圭* 李 哲熙* 鄭 輝洙* 李 淳和*

* 韓国嶺南大学環境工学科

〈水質污濁研究 Vol.14 No.1(1991) pp.38〜46〉

各種産業の発達と人口の都市集中化によって非常に污染されている河川の水質を総合的に解析するため, 調 査回数を変数とした多変量分析と，6回の調査結果を平均した水質特性值を利用して，調查地点別の多変量分 析を総合的に評価し，水質特性值および污染負荷に対する流量との関係を多変量分析による因子得点と比較し た。その結果，調査回数別の傾向がほとんど一致することから，季節的に水質が同質性を表していることが認 められた。

また，第三主成分までの累積寄与率が $97.8 \%$ の高い值を示し，第一主成分には水温を除外した 14 種の水質特 性の因子負荷量が 0.9 以上であり，因子得点は流量と明らかな関係が認められた。しかし，点污染源による主影 響を受ける琴湖江下流では，河川流量変動による污染物質の流達率の変動はほとんどなかった。 